sized urban areas. The second question has to do with the impact of a worker's religious background once that worker left church or church-affiliated organization. The evidence suggests a preference for Communism among Catholic workers as opposed to Social Democracy. The reasons for this, Wheeler suggested, were only partly religious, e.g., Catholic working class protest votes would more likely have gone to a party which rejected the Weimar system (the Communists) than to a party which, like the Center, supported it (the Social Democrats).

Brian Peterson also stressed the importance of Catholic social programs in retaining the loyalty of Catholic workers. In addition. Peterson felt, Catholicism in both its theological message and its more theatrical liturgy had more appeal to workers and peasants than the somewhat austere moralizing of German Protestantism, which always had more appeal among the middle classes. More than Hunley and Wheeler, however, Peterson emphasized political sociology as the key to an understanding of Catholic workers' attitudes. Working class support for the Center and the Catholic labor movement was likely to come mainly from small and middle-sized industries, from smaller towns and cities and from women. At the same time, Peterson recognized that the continuing strength of the Catholic labor movement in large industries in densely populated areas - most notably the mining and steel industries in the Ruhr - had to be expalined. The reason for this, he suggested. was mainly the success of Catholic labor organizations before 1914. The Christian Trade Unions and related groups such as the Volksverein had been successful in keeping a significant number of Catholic workers out of the socialist camp and in so doing created a kind of Catholic parallel to Social Democracy: a basically reformist labor organization. After 1918, there was no particular reason for Catholic workers to shift their support to the SPD: if they rejected the entire system, the logical choice would be the Communist party. In this respect. Peterson essentially agreed with the conclusion of Wheeler.

Thomas A. Knapp

Loyola University of Chicago

\title{
THE TWENTIETH CENTURY TRADE UNION WOMAN: VEHICLE FOR SOCIAL CHANGE
}

"Few fields have greater scholarly gaps than the history of the non-professional American working woman," according to Joyce L. Kornbluh, director of the Program on Women and Work at the Institute of Labor and Industrial Relations (ILIR), a joint organ of the University of Michigan and Wayne State University. "Despite the rising interest in blue-collar "middle Americans"," she continued, "the literature on women's issues focuses mainly on those in professional, academic or executive job roles. Consequently there is both a lack of teaching material related to women's studies and labor studies, and a lack of practical information on women who are currently involved in trade union leadership."

To fill these gaps, the Rockefeller Foundation has funded the year-long oral history project, "The Twentieth Century Trade Union Woman: Vehicle for Social Change." The heart of the study 
will be interviews with fifty women who have played a significant role in promoting "union recognition, job security, better working conditions, improved child care and equal rights," in Ms. Kornbluh's words. Suggestions for individuals to be interviewed have already reached the number of 300 , since the announcement of the project in September, 1975. The unexpected number of potential informants has suggested another function for the project: identifying as many noteworthy women labor leaders as possible to serve in further studies. Responses have come from areas as diverse as academic labor historians, presidents of local unions, and Mr. Reuther. With future interviewing in mind, additional names are still being sought. If you would like to suggest a woman from any geographic area, who was an effective advocate of change in an industrial or union setting, please write to Ms. Joyce Kornbluh at the Institute for Labor and Industrial Relations, 108 Museum Annex Building, Ann Arbor, Michigan 48104.

Members of a nationally representative advisory committee have already begun to make policy decisions that will shape the project. At a recent meeting in Ann Arbor, the project director, Lydia Kleiner, a doctoral student in American Studies, spoke on several aspects. At an earlier meeting in New York, she reported, the possibility of cooperating with a national consortium in Oral History was explored. Such a link would extend interviewing resources in areas removed from Detroit/Ann Arbor, and it would also provide interested Oral Historians with valuable subjects. A number of labor historians around the country have already volunteered to interview women in their areas. Consideration was also given to the kind of questions to be asked. Sentiment in New York and Ann Arbor held for non-directive guidelines which would elicit a certain amount of common information while giving the interviewer the freedom to follow up spontaneous cues. Issues of storage and dissemination received continued discussion. The tapes are to be duplicated and distributed to various centers around the country. Ms. Kleiner reported that the Comell Library was being considered as one of the natural repositories of tape copies, since it is systematically gathering trade union documents. Philip Mason, director of the Labor Archives, Wayne State University and Robert M. Warner, director of the Michigan Historical Collections offered their professional advice on problems of storing, transcribing and duplicating tapes. They also brought into focus some of the problems involved in legal release of tapes and transcripts. The crucial substantive issue under discussion in both meetings centered on criteria for choosing those to be interviewed. Rejecting a distribution of individuals who would represent all ages, races and geographic areas, Professor Louise Tilly, Director of Women's Studies at the University of Michigan opted for interviewing the oldest candidates first. Professor Robin Jacoby agreed that emphasis should be placed on getting tapes of women who had never been interviewed before.

The participants in this project hope that the collection of interviews will provide raw material for studies in the history of the American labor movement and curricular materials. The aim is to see to it that women who made contributions to improving the life of the working people are no longer "ephemeral" members of urban histories or invisible participants in the labor movement.

\author{
Daryl M. Hafter \\ Eastern Michigan University
}

